\title{
In the Image of Lucifer
}

\author{
Sakti Sekhar Dash \\ Ravenshaw University \\ Odisha, India \\ saktisekhardash96@gmail.com
}

\begin{abstract}
The image of Judge Holden evokes the image of a sinister seven-foot-tall, completely hairless man, who is the arch-nemesis of humanity. A man of vast erudition, Holden is also the most savage of the lot riding alongside John Joel Glanton. The figure of Judge Holden has drawn comparisons to the character of Captain Ahab and the great white whale, Moby Dick.

But Judge Holden also brings to mind the character of Lucifer. Both of them emerge as enemies of humanity and appear awe-inspiring even in their fallen state. It must not be forgotten that they had possibly glorious pasts. But they made choices that led them to become sinister and malevolent characters. Their depravity and fallen state are in stark contrast with their intellectual refinement. Lucifer features prominently across the myths of different cultures. In most representations, he appears as the "bearer of light." A celestial figure, close to God, Lucifer becomes a damned and fallen figure, the avowed enemy of humanity.
\end{abstract}

Keywords: Violence, Anarchy, Malevolence, Evil 


\section{Introduction}

With the publication of Blood Meridian, Cormac McCarthy created a stir. Many found the violence outright revolting. Yet beneath the veneer of the violence was a puzzle, an enigma. The character of Judge Holden baffled readers and critics alike. The enormous presence of the Judge casts an ominous shadow throughout the novel. Despite his sheer horrific acts, the reader cannot look away. Despite the morbid nature of his deeds, the reader is drawn towards the enigmatic character of Judge Holden.

In a physical sense, the Judge appears extraordinary. He is a giant of a man, close to seven feet tall, completely hairless, and he is an albino. His striking physical appearance sets him apart from the rest of humanity. He is "a monstrous, hairless, compellingly astute killer who comes to seem immortal by book's end" (Hage 11). His capacity for evil places him on a similar platform as that of Lucifer. Just like the fallen angel, Judge Holden relentlessly wages war against humanity. He revels in chaos, anarchy, and bloodshed. When the Judge is introduced in Blood Meridian, he is found to be exhorting a mob to lynch a priest. He does it to amuse himself, to satiate his malevolent intentions. As Tobin recounts, the origins of the Judge remain shrouded in mystery. Glanton's gang came across him, perched on a rock in the middle of the vast desert. It appears as if he was waiting for the group. It is a scene that mirrors the events of Book I of Paradise Lost.

In Paradise Lost, once he frees himself from his bonds and gets out of the lake of fire, Lucifer calls upon his fellow angels. He waits for them and the legion of fallen angels throng to him.

Hovering on wing under the Cope of Hell

'Twixt upper, nether, and surrounding Fires;

Till, as a signal giv'n, th' uplifted Spear

Of thir great Sultan waving to direct 
Thir course, in even ballance down they light

On the firm brimstone, and fill all the Plain; (Milton 345-350)

Lucifer had been one of the most glorious of the angels. He enjoyed a hallowed position in heaven. Across different cultures, he is known under different names. But almost invariably, he is associated with light. In Mesopotamian religion, Inanna or Ishtar is closely tied to Venus or Astarte. In the ancient Canaanite religion, Attar tried to take the throne of Ba'al. failing to do so, he chose to rule the underworld. In classical myths, Lucifer is the name ascribed to a light-bearing divinity. In Metamorphoses Ovid describes Lucifer as the brightest of the heavenly bodies.

Lucifer, that star that beckons all mankind

To dally rounds, came up the sky. (Ovid 113)

In Milton's Paradise Lost, Lucifer is synonymous with Satan. With his fall from heaven, he loses his former name and glory. The brightest angel of heaven cuts a sorry figure in Paradise Lost as he is reduced to a pale shadow of his former glorious self. This fallen state seems to parallel the condition of Judge Holden.

The huge, pale, hairless man seemed to be beyond the clutches of time. He does not sleep, he does not grow old and, in all likelihood, he will not die. "Judge Holden also inhabits Blood Meridian as a partially supernatural entity. His entry into the Glanton Gang comes after he miraculously appears on the plain, calmly sitting on a lone rock in the middle of nowhere"(Hage 47). Though John Joel Glanton is the leader of the murderous troop, it is the Judge's malevolent will that functions as the guiding agent. Yet in many ways, he is different from the others riding in the gang. "The Judge's uncanny dancing, fiddling, intellectual and lingual capacities set him apart from the other brutal killers in the Glanton Gang" (Hage 54).

War and Great Ambitions 
Time and again, Judge Holden calls himself "a true dancer" (McCarthy 331). But his dance is one of destruction. It is a dance rooted in war: an endless war waged against God's creation. Glanton's Gang set out on purpose- to hunt down the native Indians who posed a threat to the settlers. But gradually it degenerates into a massacre, a ritual of blood and murder. It is the Judge's prodigious intellect that guides this madness. His actions are hard to explain, and yet it is clear that the deeds are the outcome of a malignant will.

In the First Book of Paradise Lost Lucifer or Satan proclaims:

We may with more successful hope resolve

To wage by force or guile eternal Warr

Irreconcileable, to our grand Foe,

Who now triumphs, and in th' excess of joy

Sole reigning holds the Tyranny of Heav'n. (Milton 120-124)

Lucifer rose in rebellion when God chose The Son as his successor. Lucifer himself aspired to the throne of heaven. Being one of the most divines of the celestial beings, he looks upon the highest seat of heaven as rightfully his. When that is denied to him, he rebels against the Almighty. Despite his subsequent defeat, he remains unmoved in his resolve to war against the Divine. Though his angelic grace has been irretrievably lost, yet we see a monstrous intellect at work.

"All is not lost; the unconquerable Will,

And study of revenge, immortal hate,

And courage never to submit or yield: (Milton 106-108)"

In the subsequent Books of Paradise Lost Milton provides us with an account of Satan's endeavours to corrupt God's creation. Dwelling in a fallen state, he becomes the archenemy of God and everything associated with Him. In other words, he becomes the mortal enemy of humanity. When he sees Adam and Eve in their blissful innocence, he is shaken to 
the core. He is reminded of his past. As an angel of God, he had enjoyed glory. It is hard for him to tolerate something pure and untainted. It gives him a perverse delight in corrupting man.

On a similar note, Judge Holden takes a perverse pleasure in snuffing out lives. He is indifferent to the murders he commits or those that are committed around him. He is the high priest of a ritual that is 300,000 years old. The scalp hunting tradition is at once primitive and at the same time, a reflection of the violence that man has inherited. Evidence of an Indian's death depended on a hunter producing a scalp. “And an Indian's scalp was dearer to him than is immediately obvious." (Speich 6). It is a symbolic act which deprives the Indian of gaining Paradise. Just as Satan deprives Mankind's first parents of their rightful place in Eden, likewise, Judge Holden and the murderous horde riding with him deprive the people they come across of their lives and in doing so cut them off from their passage to Paradise.

Amidst all this is Judge Holden's obsession with intellect and knowledge. Whenever they are not on the move, he spends his time studying plants, wildlife, minerals, and language. He notes down his findings in a ledger. "Whatever exists, he said. Whatever in creation exists without my knowledge exists without my consent" (McCarthy 149). Like a malevolent god, he desires to control everything. He aspires to take the reins of everything into his own hands. Just as Satan aspires for the highest seat of heaven, only to be cast down, likewise Holden aspires to gain knowledge regarding the entirety of the creation. Both of them are waging war against God and humanity. As a result, they desire to gain an extensive knowledge regarding His creation. After his escape from Hell, one of Satan's first actions was to find out about Eden and Man. For him, God's finest creation “exists without his consent." 


\title{
Agents of Anarchy
}

If Lucifer plunged the heavenly realms into chaos and anarchy, Judge Holden unleashed pandemonium along the Mexican borderlands. Lucifer, along with his fellow angels, rebelled against the authority of God. They tried to seize by force what was not rightfully theirs. It is by his own choice that Lucifer abandons the heavenly splendours. When he goes up in arms against God, he severs his ties with the divine and the glorious. He becomes an unholy and damned entity, eternally condemned.

\author{
"Farewel happy Fields \\ Where Joy for ever dwells: Hail horrours, hail \\ Infernal world, and thou profoundest Hell \\ Receive thy new Possessor: One who brings \\ A mind not to be chang'd by Place or Time. (Milton 249-253)"
}

In his fallen state, Lucifer aligns himself against God. His sole motive is to corrupt God's creation, to cause ruin and anarchy that would bring pain to the Creator. His pursuit of vengeance leads to chaos and anarchy in the creation. He tempts Eve, our 'first mother,' and that leads to the fall of Man. Satan takes a perverse pleasure in depriving Adam and Eve of the glory of Eden. "Satan, we find out, is an emissary from Hell and the Titanic adversary of God attempting to destroy the world and conquer God's new creation, the race of mankind" (Loewenstein 30). He is also responsible for bringing Sin and Death to earth. Humanity, which was born in grace, and glory, becomes the victim of sin, and death. They fall into the clutches of strife, discord, and violence. Michael shows the grim future of humanity- one haunted by disease, plagues, famines and death. Along with that, Michael reveals the horrors of murder and violence. 
Lucifer intended to corrupt humanity, to cause pain and misery. And he succeeds in his designs. Satan's evil venture continues with Judge Holden. Time and again, he makes references to a "great dance," and the dance is nothing but war. He is part of a murderous horde whose sole aim is to take as many lives as possible. He revels in anarchy and chaos. Glanton's gang had set out on a mission to hunt down Indians, but pretty soon, they start murdering one and all. They unleash mayhem in the towns they camp in. Judge Holden's desire is to gain a complete knowledge regarding the creation and to unmake what exists without his consent. Values like compassion and morality hold no meaning for him.

\section{The Great Evil}

Cormac McCarthy's creation, Judge Holden, has been regarded as one of the vilest and one of the most villainous characters in literature. He has no qualms in taking the lives of children. He is a Satanic figure who goes to extreme lengths to satiate his evil intentions. Much like Iago and Lucifer, the Judge has a malevolent will. He desires death and destruction as he is a sworn enemy of life and humanity. He is a reflection of the evil that will never die. Evil took root in humankind when Adam and Eve partook of the forbidden fruit. Satan was responsible for Man's fallen ways. Judge Holden takes it to new depths. He is a manifestation of the evil that will never die. "He is truly the most degenerate and villainous character in the novel, yet he is the most refined as well" (Hage 48). There is simply no escaping the evil that has assumed the shape of Judge Holden. Years later, when The Kid comes across the Judge, the latter has not changed a bit. Despite confronting the Judge with courage, the Kid is no match for him.

“In McCarthy's dark worldview, the kind of timeless evil that Judge Holden represents must ultimately triumph"(Hage 48). The Kid's moral courage is inadequate to 
overcome the Judge Holden's evil. “On Holden's rifle is inscribed the Latin saying: “et in Arcadia ego," a saying that translates to "even in Arcadia I am present," which sounds like a platitude issued from the lips of a personified death" (Hage 47). He is the image of Lucifer or Satan who walks across the borderlands of Mexico and America, dealing out death to humanity. 


\section{Works Cited:}

McCarthy, Cormac. Blood Meridian. New York: Vintage, 1985. Print.

Hage, Erik. Cormac McCarthy: A Literary Companion. North Carolina: McFarland \& Company, 2010. Print.

Speich, John. Notes On Blood Meridian. Austin: University of Texas Press, 2008. Print.

Ovid, Tr. Horace Gregory. Metamorphoses. New York: The Viking Press Inc., 1958. Print

Milton, John. Ed. Barbara K. Lewlski. Paradise Lost. Malden: Blackwell Publishing, 2007.

Print.

Loewenstein, David. Landmarks of World Literature Milton Paradise Lost. Cambridge:

Cambridge University Press, 2004. Print. 